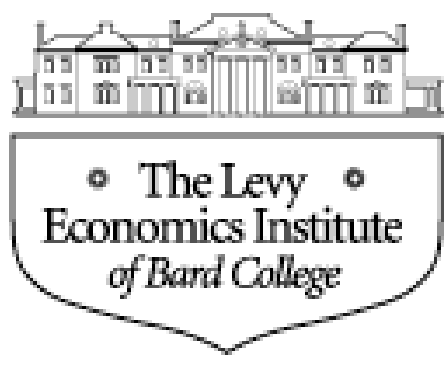

Working Paper No. 391

\title{
Aggregate Demand, Conflict, and Capacity in the Inflationary Process
}

\author{
By \\ Philip Arestis. \\ The Levy Economics Institute of Bard College \\ and \\ Malcolm Sawyer, \\ The Levy Economics Institute and University of Leeds
}

The Levy Economics Institute Working Paper Collection presents research in progress by Levy Institute scholars and conference participants. The purpose of the series is to disseminate ideas to and elicit comments from academics and professionals.

The Levy Economics Institute of Bard College, founded in 1986, is a nonprofit, nonpartisan, independently funded research organization devoted to public service. Through scholarship and economic research it generates viable, effective public policy responses to important economic problems that profoundly affect the quality of life in the United States and abroad.

The Levy Economics Institute P.O. Box 5000

Annandale-on-Hudson, NY 12504-5000

http://www.levy.org

Copyright $(C$ The Levy Economics Institute 2003 All rights reserved. 


\section{INTRODUCTION}

This paper sketches out the key elements of what we term a structuralist view of inflation. It is one that concentrates on four key elements: the role of aggregate demand; endogeneity of money; the role of productive capacity; and conflict over the distribution of income. In section 2 we elaborate on these four key elements. In section 3 we provide a formal treatment of some of the key elements of the structuralist view of inflation. In section 4 we bring forward empirical considerations in support of the theoretical model of inflation. A final section, section 5, summarizes and concludes.

\section{THE KEY ELEMENTS OF THE MODEL}

In this section the elements of a structuralist view of inflation is sketched, which combines elements of Keynesian, Kaleckian and Institutionalist macroeconomics. It is argued that there are four key elements of this view of inflation (and more generally on the macroeconomic workings of a market economy). We begin by observing that inflationary pressures emanate from two sources. The first we discuss is the level of aggregate demand in relation to productive capacity. The second emanates from conflict over income distribution.

(i) One set of inflationary pressures comes from the level of demand relative to the size of productive capacity. There is no presumption that there is adequate capacity in an economy to support the full employment of labor, and hence enterprises may be operating at or above full capacity with substantial levels of unemployment. It has often been assumed that enterprises operate subject to (approximately) constant average direct costs and with significant excess capacity so that further expansion can be undertaken without costs (and presumably prices) rising. This "stylized fact" has often been invoked to explain some degree of price constancy with respect to the level of demand, and evidence (e.g. Sawyer, 1983) supports the view that price changes are little related with the level of (or changes in) demand. However, the view that average direct costs are broadly constant would add up to the point of full capacity, after which average costs may rise rapidly.

(ii) A related set of inflationary pressures comes from the inherent conflict over the distribution of income. The ability of the economy to reconcile the conflict depends, inter alia, on the productive capacity of the economy (the "size of the cake"). The determination of an inflation barrier (as indeed in the literature on the NAIRU and on the "natural rate of unemployment") involves the notion that wages and prices rise together with the difference 
in the rate of increase of wages and that of prices being equal to the rate of labor productivity growth. In other words, the distribution of income between wages and profits would remain constant. This serves as a reminder that there are basic conflicts over the distribution of income. If all groups and classes in society were in effect content with the existing distribution of income, then it could be expected that there would not be a problem of inflation: at a minimum it would mean that the rate of inflation was constant. An increase in inflation can be viewed as arising from some combination of intention of some groups to increase their share of income and enhanced opportunity to do so. A higher level of demand for labor may, for example, be seen as enhanced opportunity for workers to increase their share. But a related higher level of demand for output would allow firms to increase their profits. The "conflict theory" of inflation can be seen as based on this insight.

(iii) The level of economic activity depends on the level of aggregate demand, and there is no presumption that the level of demand will generate full employment of labor and/or full capacity utilization. Investment has a crucial dual role to play in our model. The first is through its impact on aggregate demand. The second is through its enhancing impact on capital stock. Further, there is no automatic mechanism, which takes the level of aggregate demand to any supply side equilibrium. The mechanisms, which feature in other approaches to economics, such as adjustment of real wages to clear the labor market, or the operation of the real balance effect, are explicitly rejected.

(iv) Money is endogenous credit money created by the banking system. Money comes into existence through the loan process, and the extent of money creation depends on the demand for loans and the willingness of banks to satisfy that demand. Loans create bank deposits, which serves as money. The stock of money remaining in existence has to be held by some agents, and hence depends on the willingness of the public to hold money (what is usually called the demand for money). While the stock of money and nominal income rise broadly in line with each other, the direction of causation runs from nominal income to stock of money. The importance of endogenous money in our model emanates from the creation of loans aspect of it, which enables aggregate demand to take place.

In the discussion below we refer to an "inflation barrier," which corresponds to the level of economic activity for which inflation would be constant. If the level of aggregate demand pushes the level of economic activity much above that "inflation barrier" (and particularly if the rise in economic activity is rapid) then inflation rises. This "inflation barrier" has some similarities with a Nonaccelerating Inflation Rate of Unemployment (NAIRU), but there are some important differences, at least of interpretation. The first 
difference is that the NAIRU approach is generally embedded in a view that the level of demand will adjust to the NAIRU, usually through the operation of some form of the real balance effect. ${ }^{1}$ In the approach developed here since money is treated as endogenous, there is no real balance effect, and we do not envisage that aggregate demand adjusts to the inflation barrier. Second, in the NAIRU approach there is a form of separation between the supply-side and the demand-side of the economy. In contrast here we stress that aggregate demand influences (and is influenced by) the rate of investment, which changes the capital stock, thereby having supply-side effects of productive capacity. This would also imply that the inflation barrier is continuously changing as investment occurs, and there is no implication that the inflation barrier remains unchanged over time. Third, the NAIRU approach has become associated with the idea that the structure of the labor market (notably the degree of rigidity or flexibility, however those terms may be defined) is the major determinant of the size of the NAIRU (and thereby of the level of unemployment). While, as will be indicated below, the conditions of the labor market may have some impact on the inflation barrier, it is not seen as a major determinant.

\section{A STRUCTURALIST VIEW OF INFLATION}

The key features discussed in section 2 enables us to set up a model that captures a structuralist view of inflation. There are three segments to this model that capture the elements discussed in section 2. These are a wage equation, a price equation and an investment relationship. We begin with the wage equation.

\subsection{Wage Equation}

There are numerous views as to how wages are determined. Our approach differs substantially from those that view wages as set in a competitive labor market. At least in terms of the algebraic representation of the equilibrium relationship between real wages and employment, many of the approaches that are compatible with ours lead to similar outcomes-for example trade union bargaining models, efficiency wage models (for more

\footnotetext{
${ }^{1}$ For example, in their influential book, Layard, Nickell and Jackman (1991) portray aggregate demand as $y_{d}=\sigma_{11} x+\sigma_{12} r^{*}+\sigma_{13}(m-p)+\sigma_{14} D p e+\sigma_{15} c^{*}$

where $x$ includes fiscal stance, world economic activity and world relative price of imports; the foreign real rate of interest is $r^{*}=I^{*}-D p^{*} e$ (nominal rate of interest minus expected foreign inflation), $m-p$ is (log) real money supply, Dpe expected inflation and $c^{*}$ expected long run competitiveness. It can be readily seen that if the level of demand $\left(y_{d}\right)$ is to adjust to the level of output as set on the supply side, one or more of the variables
} 
details see Sawyer, 2002, and Layard, Nickell and Jackman, 1991, especially chapters 8 and 9).

We draw upon the target real wage hypothesis (Sargan, 1964; for detailed elaboration see Sawyer, 1982a, 1982b) based on a collective bargaining view of wage determination which can be set out as:

(1) $\dot{w}=a_{1}+a_{2} \dot{p}_{-1}+a_{3} U+a_{4}\left(w_{-1}-p_{-1}-T\right)$

where dot over variable indicates rate of change, $w$ is log of money wages, $p$ is log of prices, $U$ is rate of unemployment and $T \log$ of target real wages, the coefficient $a_{2}$ may be close to unity, $a_{3}$ and $a_{4}$ are signed as negative. The rate of nominal wage increase depends on rate of inflation, unemployment (reflecting bargaining power) and the difference between actual real wages and target real wages.

The equilibrium relationship when the rate of wage change equals the rate of (lagged) price change is given in equation (2):

(2) $a_{1}+a_{3} U+a_{4}(w-p-T)=0$

assuming for convenience that $a_{2}=1$. Defining unemployment as $U=\left(L_{\mathrm{f}}-\mathrm{L}\right) / L_{\mathrm{f}}$ where $L_{\mathrm{f}}$ is full employment (assumed given) and $L$ is actual employment, yields

(3) $\frac{L}{L_{f}}=\frac{a_{1}}{a_{3}}+1+\frac{a_{4}}{a_{3}}(w-p-T)$

which gives a positive relationship between real wage and employment and is drawn as the w-curve (which reflect the wage determination process) in Figure 1. The inflationary dynamics (from equation 1) are such that for points below the w-curve wages rise faster than prices, and for points above wages rise less rapidly than prices. In terms of Figure 1, the position of the w-curve depends on the coefficients $a_{1}, a_{4}$ and the target real wage. In representational terms, any factor which could be viewed as changing one (or more) of those parameters would lead to a shift in the w-curve, and thereby in the inflation barrier.

\subsection{Price Equation}

We consider our price equation at two levels: first at the enterprise level and then at the aggregate level.

on the right hand side of the equation have to adjust. In this formulation, this would involve some combination of the fiscal stance, the real money supply and the expected rate of inflation. 


\section{Enterprise Level}

The short-run profit maximizing decision facing the enterprise is given by maximizing profits as in (4):

(4) $\Pi=P(q, Z) \cdot q-W . l$

where $q=f(l, k)$, with $f_{1}$ (the first partial derivative of $f$ with respect to $l$ ) is positive, and $f_{11}$ (second derivative with respect to $l$ ) is seen as being initially positive and then negative (so that the marginal productivity of labor initially increases with the amount of labor and then declines). Furthermore, $P$ is price charged by the firm, $q$ enterprise output, $Z$ is a vector of variables influencing the demand facing an enterprise including the level of aggregate demand, $W$ the enterprise nominal wage, and $l$ the labor input. Material inputs are omitted since their inclusion would complicate the analysis without being of importance to the points we wish to explore here.

Using the level of employment as the key decision variable, with the capital stock and $Z$ held constant, the first order condition for profit maximization yields:

(5) $\quad d \frac{(e-1)}{e} \alpha(l)^{\alpha-1} k^{1-\alpha} f_{1}\left(l^{\alpha} k^{1-\alpha}\right)=\frac{W}{P(q, Z)}$

where $f_{1}$ is the first partial derivative of $f$ with respect to the first argument and $e$ is the elasticity of demand.

This equation provides only a point outcome: it is an equation in $l$ ( $k$ being treated as given at this point; $P$ and $q$ being functions of $l$ ), which can be solved to give the level of employment, from which the level of output, real wage and price can be derived. In order to map out a relationship between real wage and employment based on equation (5), it is necessary to vary some exogenous variable. One way to map out a relationship between the real wage and the level of employment is to allow the $Z$ variable (measure of aggregate demand) to vary, with the intensity of labor constant at the level set by the optimal (for the enterprise) wage. In particular, movements in the level of aggregate demand would generate movements in employment, real wage etc..

Equation 5, therefore, is now written in the form:

(6) $W / P=m(c u) f_{1}(l, k)$

where $m$ is the inverse of the mark-up of price over marginal labor costs and it is expected that $m_{l}$ (first derivative of $m$ ) is positive (i.e. mark-up falls) for low values of $u$ but negative for relatively high values, and the $Z$ (aggregate demand variable) is suppressed. 


\section{Aggregate Relationship}

Lower case letters are used to signify quantities at the enterprise (plant) level and upper case aggregates. When there are $n$ enterprises (plants), the aggregate output $Q$ is given by :

(7) $Q=n q=n f(l, k)$

where $\mathrm{n}$ is number of enterprises (plants). The "normal" level of capacity of enterprise is denoted by $q^{*}$. Capacity utilization is $c u=q / q^{*}$, and the mark-up of price over marginal costs is taken to be a function of $\mathrm{cu}$. Now,

(8) $c u=q / q^{*}=f(l, k) / q^{*}$

with $L=n l$, and substituting into (6), we have:

(9) $W / P=m\left(f(L / n, k) / q^{*}\right) f_{1}(L / n, k)$

so that

$$
W / P=m(v f(L / n, k) / k) f_{1}(L / n, k)
$$

where $v$ is the ratio of capacity output to capital stock, i.e. $k=v \cdot q^{*}$.

The relationship between $W / P$ and $L$ in equation (10) is drawn as the p-curve in Figure 1. The p-curve reflects the relationship between the real wage and employment derived from price determination considerations. The position and shape of that curve will shift with changes in $n$ and in $k$. This p-curve represents (since it has been derived from profit maximizing considerations) the optimal real wage (from the enterprises' perspective). The dynamics would be that from points above the p-curve, prices would rise faster than wages, and for points below, prices would rise less rapidly that wages. It should also be noted that movements along by p-curve would be generated by changes in the level of aggregate demand: in effect for a given level of aggregate demand enterprises would pick one point on the p-curve (corresponding to profit maximization).

It can be readily shown that the sign of $\mathrm{d}(W / P) / \mathrm{d} n$ depends on $m_{1}$ and $f_{11}$ : at low levels of capacity utilization with $f_{11}>0, \mathrm{~d}(W / P) / \mathrm{d} n$ is likely to have a negative sign (in effect more plants, lower output per plant and higher unit costs), whereas with high levels of capacity utilization, with $f_{11}<0$ and $m_{1}<0$, then $\mathrm{d}(W / P) / \mathrm{d} n$ has a positive sign. The position of the p-curve depends on the size of the capital stock: the larger the capital, the further to the right will the p-curve be. The height of the p-curve depends on the capital intensity of production and the market power of enterprises. The greater the market power, the higher the price and the lower the real wage: hence the lower the p-curve. The sign of $\mathrm{d}(W / P) / \mathrm{d} k$ will be positive when $m_{1}$ and $\left(f_{2}-f / k\right)$ are both negative, that is when the inverse of mark-up falls with higher capacity utilization, and marginal product of capital is below average product. 
Equations (3) and (10), drawn in Figure 1 as the w-curve and the p-curve respectively, involve real wages and employment and could be solved to give a supply-side equilibrium akin to an inflation barrier. The inflation barrier is formed by the interaction of price and wage determination, which is in terms of Figure 1 the intersection of the p-curve and the wcurve. Since the p-curve depends on the size of the capital stock and the number of firms, so will the position of the inflation barrier.

This does not imply that the economy will operate at or even tend towards that supply-side equilibrium - the level of economic activity will be set by the level of aggregate demand with no market forces tending to move the level of aggregate demand towards the inflation barrier. ${ }^{2}$ Equation 10 (treated as a relationship between real wages and employment) will shift over time as the number of firms and the capital stock per firm change. The inflation barrier would be constantly changing as investment occurs. There is an in-built form of hysteresis in this approach-since the time path of aggregate demand influences investment, which causes the capital stock to change. In general a rise in the number of firms will shift the p-curve down for low levels of employment but up for high levels of employment. An increase in the capital stock per firm will in general shift the pcurve upwards. An upward shift in the p-curve around the previous point of (supply-side) equilibrium would be associated with higher levels of real wages and of employment. ${ }^{3}$

\subsection{Investment}

The approach to investment is Kaleckian in spirit (cf. Kalecki, 1943), with factors such as profitability and capacity utilization impacting on investment. The significant aspect of investment is that it is sensitive to the level of aggregate demand, and that there is not an optimal capital stock which is solely determined by relative prices.

The rate of investment relative to the capital stock $K$ is a positive function of the rate of profit $(\Pi)$, and capacity utilization $(\mathrm{cu})$, i.e.

$$
I / K=b_{0}+b_{1} \Pi+b_{2} c u
$$

This can be mapped into a function of real wages and employment to give:

$$
I / K=b_{0}+b_{1}[1-(W / P)(L / Y)](Y(L, K) / K)+b_{2} Y(L, K) / K
$$

since the share of profits is given by the expression: $[1-(W / P) .(L / Y)]$, and $K$ is a measure of capital stock. In the context of a net investment function and a no-growth economy (or

\footnotetext{
${ }^{2}$ There may be policy forces that do so. For example when monetary policy is set according to some form of Taylor's rule, then insofar as that is effective, demand will be diminished when inflation is high and/or rising.

${ }^{3}$ For an extended treatment of the p- and w-relationships, see Sawyer (2002).
} 
treating all appropriate variables as normalized on the underlying rate of growth), the condition of a constant capital stock gives:

$$
b_{0}+b_{1}(1-(W / P)(L / Y)) \cdot(Y(L) / K)+b_{2} Y(L) / K=0
$$

from which a zero (net) investment locus can be obtained which involves a positive relationship between the real wage and employment. Two possible positions of the zero investment locus are drawn in Figure 1. IA when "animal spirits" are high and IB when they are low (investment is more often positive for IA than for IB). When aggregate demand is relatively high, then the economy would be operating to the right of the zero investment locus-net investment is positive, the capital stock is rising and the p-curve would be shifting upwards.

It is important that this Figure is not interpreted in isolation with some idea that the inflation barrier is a supply-side equilibrium towards which the economy tends. We repeat the point above that there are no automatic forces pushing the economy towards the point where the p- and w-curves meet each other. Further the course of the economy cannot be understood without reference to the level of aggregate demand. In this context, aggregate demand is important not only in that it determines the level of economic activity (which may have some effect on the rate of inflation), but also through its influence on the rate of investment. The evolution of the capital stock would ensure that the stock of productive capacity changes, and that would be reflected in terms of a shift of the p-curve in Figure 1. It is also necessary to recall that money is viewed as endogenous, and hence as inflation proceeds, the stock of money will expand, but there is little point in attempting to control inflation through monetary policy (particularly through control of the money supply); inflation is not a monetary phenomenon.

The level of aggregate demand in this framework can be derived (taking the case of a closed private economy for reasons of simplicity) by equating savings and investment, i.e. with a differential savings propensity out of wages and profits this is:

$$
b_{0}+b_{1}\left(1-\left(\frac{W}{P}\right)\left(\frac{L}{Y}\right) \cdot\left(\frac{Y(L)}{K}\right)+b_{2} \frac{Y(L)}{K}=s_{0}+s_{1}\left(\frac{W}{P}\right)\left(\frac{L}{Y}\right)\left(\frac{Y(L)}{K}\right)+s_{2}\left(1-\left(\frac{W}{P}\right)\left(\frac{L}{Y}\right)\left(\frac{Y(L)}{K}\right)\right.\right.
$$

This can be re-arranged to give:

$$
\left(b_{0}-s_{0}\right) K+\left(b_{1}+b_{2}-s_{2}\right)\left(\frac{Y}{L}\right)=\left(s_{1}-s_{2}+b_{1}\right) \frac{W}{P}
$$

The sign of this relationship may be positive or negative: in the terms of Bhadhuri and Marglin (1990) analysis, it will be positive if there is a stagnationist regime and negative if there is an exhilarationist regime. If the Keynesian stability condition applies, then $b_{1}+b_{2}-$ 
$s_{2}$ will be negative, and hence the sign of the relationship depends on $s_{1}-s_{2}+b_{1}$. In Figure 2, the AD curve represents equation (15) under a stagnationist regime: the position and slope of the $\mathrm{AD}$ is arbitrary. It illustrates that demand differs from the inflation barrier, and the position of the $\mathrm{AD}$ curve will influence, in conjunction with the prevailing real wage, the level of economic activity and the pace of inflation.

The p-curve and the w-curve may have substantial ranges over which they are near to horizontal, and if that is so, then any precise identification of the inflation barrier would be difficult and indeed the inflation barrier would be more like a plateau than a point. Further, since investment is always taking place, the p-curve would be continually shifting (even if that leads to rather small changes in the inflation barrier). It would also mean that inflation would be slow to rise (fall) as unemployment is lower (higher) than the point of intersection of the two curves in Figure 1.

Three propositions follow from the analysis so far.

1. The position of the "inflation barrier" (akin to a NAIRU) depends on the size and composition of the capital stock. A larger capital stock per firm and a greater number of firms (often but not always) leads to the "inflation barrier" being at a higher level of employment with a higher real wage.

2. A larger capital stock will permit a higher level of aggregate demand (and higher level of employment, and lower rate of unemployment) without inflation tending to rise.

3. Investment depends on factors such as capacity utilization and profitability, which in turn are related to the level of aggregate demand. Hence, the evolution of the capital stock depends on the time path of the level of aggregate demand. Higher levels of aggregate demand lead to more investment, and over time a larger capital stock.

4. Changes in labor market "flexibility" in terms of variations in wage differentials, changes in "hiring and firing" practices would be seen to have little effect on the inflation barrier. Where some effect may be present is when changes in, for example, trade union power, which is reflected in either the ambitions of workers in terms of the target real wage or in their ability to secure higher wages (reflected in the $\mathrm{a}_{1}$ coefficient), would shift the wcurve. For example, a reduction in worker power shifts the w-curve downwards, thereby leading to an inflation barrier that involves higher employment. It would also be the case that changes in the power and/or profit ambitions of enterprises would impact on the inflation barrier: greater market power, shifting the p-curve downwards, would tend to reduce real wages and employment. 


\section{EMPIRICAL CONSIDERATIONS}

The approach to inflation, which has been sketched in the previous section, suggests a significant role for productive capacity and investment. The view is taken that there is no presumption that productive capacity is always sufficient to fully employ the work force, and that the level and composition of investment over time influences the evolution of the capital stock. There is then no presumption that there is some predetermined equilibrium capital stock such that the actual capital stock converges on that equilibrium stock. Since net investment is rarely zero (and generally positive), the capital stock is always changing, and hence the precise position of the inflation barrier is always changing. In what may be termed normal times, changes in the capital stock will be rather small with little by way of change in the inflation barrier. But times of major recession or of war reduce the capital stock substantially (at least relative to trend). In the other direction a prolonged investment boom increases the capital stock (relative to trend) substantially.

Dow (1998) argues "that in a major recession underemployment results in the deterioration and premature scrapping of physical equipment, and that disbandment or underemployment of a firm's workforce similarly results in the partial destruction of working practices and working relations. The latter constitute the intangible capital of a firm, the value of which is an important fraction of its market value as a going concern. The capital stock, physical and intangible, takes time to build up, and its destruction cannot be made good rapidly; in effect, therefore, the destruction is quasi-permanent. In this way demand shocks impact on supply. A major recession causes a downward displacement of the growth path of productivity (or potential or capacity output); after the recession, the "stable growth" mechanism described by the first mechanism will in the absence of further shocks start to operate again; i.e. normal growth will be resumed from the low point of the recession" (p. 369). He produces estimates of the impact of five major recessions in the UK, which are summarized in Table 1.

The significance of this is that it implies that substantial (negative) changes in capacity can occur as the result of recession, which have long lasting effects, and is quite consistent with the views we have outlined above. Below we consider the falls in unemployment in the UK, U.S. and Canada during the 1990s, which occurred without an upswing in inflation, and argue that the major investment boom of the 1990s underpinned the falls in unemployment. 
In this section we attempt to throw some light on the four issues raised towards the end of the last section. We begin by looking at the relationship between capital stock and unemployment. This covers the first two issues raised in section 3. Two further sections, one on the determinants of investment, and another on "labor market flexibility" complete the list. A brief section on regional unemployment renders support to our thesis on "labor market flexibility."

\subsection{Capital Stock and Unemployment}

The increases in the level of unemployment experienced in the 1980s and into the 1990s as compared with say the 1960s (especially in Europe) were substantial. The oil price shock of the mid 1970s could be seen as effectively reducing capacity as heavy energy using plant and equipment became unprofitable. High levels of unemployment and excess capacity can be expected to have lead to a substantial reduction in the capital stock below what it would have been if there had been sustained full employment, and on the basis of the argument developed above, the increase in the inflation barrier correspondingly substantial. In some respects, this says little more than enterprises will adjust the capital stock to the prevailing demand for output (and level of employment). But it suggests a clear mechanism through which the level of (un)employment experienced will be reflected in the estimated NAIRU.

There is evidence to support this view, though the empirical work to which we refer has been undertaken within frameworks that have some similarities to the one outlined here, albeit with some differences as well. Arestis and Mariscal (1997) conclude from their empirical work for the UK (1966 to 1994) that "unemployment is significantly determined by capital shortages. Capacity is not fixed and investment depends on expected profitability and the expected long-term rate of interest" (p. 191). In a subsequent paper, they find that "the NAIRU is determined by long-term unemployment, worker militancy and the capital stock" (Arestis and Mariscal, 1998, p. 202). In work on Germany and the UK those authors (Arestis and Biefang-Frisancho Mariscal, 2000) conclude that "adverse demand shocks affect employment and investment. When shocks reverse, unemployment may not fall to previous levels due to insufficient capital” (p. 487). Miaouli (2001) utilizes annual data from the manufacturing sector of five European countries and concludes that "the empirical analysis verifies that in all countries, accumulated investment in the private sector influences employment in a positive way" (p. 23). Rowthorn (1995) finds that "when manufacturing and services are combined, capital stock has a large, statistically significant impact on employment" (p. 33), in equations estimated for a cross-section of OECD countries. So that, 
Rowthorn (op. cit.) concludes, "The problem of unemployment is ultimately one of investment" (p. 38).

Stockhammer (2004) aims "to contrast and test the NAIRU hypothesis and a Keynesian explanation of unemployment in a time series context. For the NAIRU explanation, wage push variables are key to explain the rise of unemployment in Europe, for Keynesians the slowdown in capital accumulation is" (p. 21) the key. This proposition is tested using data from the mid 1960s to the mid 1990s for Germany, France, Italy, the UK and the U.S. He concludes that "the NAIRU specification performed poorly, with only the tax wedge having a positive effect on unemployment as predicted. As to the Keynesian approach, the role of capital accumulation was confirmed. Whereas capital accumulation is robust to the specification and can be pooled across countries, the tax wedge is not. In the Keynesian specification the tax wedge has the incorrect sign, however replacement ratios are significant with the predicted sign" (p. 21).

Further support comes from Alexiou and Pitelis (2003), where a panel-based study is undertaken insufficient growth of capital stock and inadequate aggregate demand" (p. 628).

\subsection{Investment}

The role of investment in this approach is central, and we now briefly investigate the empirical validity of the proposition on investment. In a general sense, when studying the behavior of investment, we may refer to economic activity variables (such as capacity utilization), essentially based on the accelerator investment model, interest rate/cost-ofcapital variables and quantity of finance variables. The distinction between cost-of-finance and quantity-of-finance effects relies heavily on the assumption of imperfect capital markets. The imperfection of capital markets is explained by resorting to a number of factors, but asymmetric information between lenders and borrowers, which might lead to credit rationing, is the most predominant one (Stiglitz and Weiss, 1981; Bernanke and Gertler, 1989). Financial variables and constraints are explicitly included in investment models through the usage of cash flow variables in the menu of explanatory variables for investment (see, for example, Minsky, 1975; Fazzari, 1993; Fazzari and Peterson, 1993).

Financial factors as crucial determinants of investment have attracted a great deal of interest. External funds are no longer thought as perfect substitutes for internal funds, in view of the recognition that capital markets are imperfect. The quantity-of-finance variables can be internal finance variables (such as corporate profits viewed as a critical variable in terms of internal finance; high corporate profits indicate greater capacity by the corporate 
sector to generate internal funds) and external finance variables (such as the ratio of debt to investment, an external cash flow component, on the assumption that a high debt environment is less likely to provide a stable financial base necessary for investment to materialize). Internal funds and net worth variables are thought to be particularly significant variables in the study by Hubbard (1998) where the relationship between capital-market imperfections and investment is reviewed. The conclusions reached are: "(1) all else being equal, investment is significantly correlated with proxies for changes in net worth or internal funds; and (2) that correlation is most important for firms likely to face information-related capital-market imperfections" (p. 193). The importance of the external funds and cash flow variables are also emphasized in studies by Bernanke and Blinder (1988), Bernanke and Gertler (1989, 1999), and more recently by Greenspan (2002). The latter argues that "capital investment will be most dependent on the outlook of profits and the resolution of the uncertainties surrounding the business outlook and the geopolitical situation. These considerations at present impose a rather formidable barrier to new investment ..... A more rigorous and broad-based pickup in capital spending will almost surely require further gains in corporate profits and cash flows" (p. 7). Furthermore, empirical evidence, summarized by Chirinko (1993), supports the contention that "output (or sales) is clearly the dominant determinant of investment spending with the user cost having a modest effect" (p. 1881). Baddeley (2003) in a comprehensive study of investment also confirms the results of "previous analyses that capacity utilization and output have the strongest effects on aggregate investment activity" (p. 214).

\subsection{Labor Market Flexibility}

The case for labor market flexibility has been recently reiterated by the proponents of the European Economic and Monetary Union (EMU) model. Issing (2003) puts it in the following strong language in testimony before the Committee on Economic and Monetary Affairs of the European Parliament: "The lack of determination to overcome structural inefficiencies is particularly evident in the labor markets of several EU countries. Impediments to employment creation continue to exist. Measures are needed that will encourage firms to hire additional staff. These measures need to aim at reducing firms' labor costs, among other things, through reforms of social security systems that will reduce social security contributions and through reforms of the tax and benefit systems that will lower the wages at which workers are willing to supply labor. Improving employees' education and training and facilitating labor mobility could help the workforce to better react to adverse 
economic shocks. In such an environment-of enhanced labor market flexibility-policies fostering labor force participation can be very effective." Rigidities in the labor markets are actually widely held to play a key role in the explanation of high unemployment rates, especially in Europe in the 1980s and 1990s (OECD, 1994a, 1994b, 1994c; Nickell, 1997; Nickell and Layard, 1999; Siebert, 1997; Elsmeskov, Martin and Scarpetta, 1998).

Baker et al (2002) utilizing standardized unemployment rates for 20 OECD countries for the period 1980-1999, produce empirical results that are less robust and uniform across countries than what these studies show. These studies stress the "direct links" between labormarket institutions and unemployment. ${ }^{4}$ More concretely, Baker et al (2002) demonstrate that the cross-country evidence of these studies provides "no evidence" for union density, and only "mixed evidence" for the effects of unemployment benefits (both replacement ratio, the level of benefits relative to income, and duration of benefits), "active labor market" policies, and employment protection laws. As for structural reforms (or labor market deregulation), the authors argue that the usage of "the degree to which a country complied with their policy descriptions" is inappropriate. When the "volume" of reforms is used instead, there is no significant impact of structural reforms on NAIRU.

The Baker et al (2002) study poses the question of "reverse causality" in the studies they discuss, to conclude that "While clearly not universal, this evidence of reverse causation provides serious grounds for viewing test results showing a correlation between high unemployment and long benefit duration" (p. 28). Similarly, these studies downplay the empirical support of the beneficial role of collective-bargaining co-ordination and active labor-market policies. As Baker et al (2002) suggest in their assessment of this literature "While the literature is widely viewed to provide strong evidence for the labor market rigidity view, a close reading of the leading papers suggests that the evidence is actually quite mixed, as several of the studies explicitly acknowledge" (p. 43).

The study by Baker et al (2002) also provides own empirical evidence for 20 OECD countries spanning 40 years, 1960-1999. ${ }^{5}$ Different time periods are utilized and different combinations of variables. The most comprehensive measure of institutions and policies utilized can only account for a minor part of the differences in the evolution of unemployment. The evidence in this paper provides little or no support for the labor market rigidity explanation. An index of the extent of labor market deregulation in the 1990s is

\footnotetext{
${ }^{4}$ Labor market institutions are institutions (like union density) and policies (like employment protection laws).

${ }^{5}$ It is important to note that this data series covers the late 1990 s when unemployment rates fell sharply in the 20 countries included in the study's sample.
} 
constructed, but this variable too, showed no meaningful relationship between labor market deregulation and shifts in the NAIRU.

Palley (2000) examines the OECD (1994a, 1994b, 1994c) Job Strategy, which had emphasized the role of labor market reforms and flexibility in reducing unemployment. He concludes (based on regression analysis of changes in unemployment in the mid-1990s) that "actions taken to reform labor markets do not explain any of the reduction in the rate of unemployment. There is some evidence that reforms of the educational system may have lowered total employment growth, which could be the result of young people staying in school longer. There is also stronger evidence that business sector reforms have lowered total employment growth, and reduced the quality of employment by slowing the growth of full-time employment" (p. 9). As Palley suggests this is indirect support for the view that the cause of high European unemployment is macroeconomic in nature. In a further study, , Palley (2001) presents empirical evidence that supports this conclusion. By accounting for micro- and macro-economic factors, and also for cross-country economic spillovers, it is concluded that unemployment in Europe emanates from "self-inflicted dysfunctional macroeconomic policy" p. 3.

An OECD (1999) study is more damning to the "labor-market-flexibility" thesis. It covers the period late 1980 s to late 1990s and utilizes new and improved data on employment legislation in 27 OECD countries. It utilizes multiple regression analysis and techniques, so that it is able "to control for other factors that can influence unemployment" (p. 88). The study demonstrates that employment protection legislation (a measure of labor market flexibility) has small or no impact at all on total unemployment. ${ }^{6}$ Consequently, dismantling employment protection would not solve the current unemployment malice in the 27 countries considered in the study.

\subsection{Regional Disparities of Unemployment}

There are generally considerable variations in the rate of unemployment across the regions of an industrialized market economy: there are, of course, other important variations in rate of unemployment, e.g. between ethnic groups. For convenience, we will refer here to regional variations.

\footnotetext{
${ }^{6}$ The employment protection legislation is defined broadly and covers all types of employment protection measures resulting from legislation, court rulings, collective bargaining or customary practices. The OECD (1999) study considered a set of 22 indicators, summarized in an overall indicator on the basis of a four-step procedure (pp. 115-118).
} 
The labor market interpretation of the NAIRU stresses the role of labor market institutions, laws and regulations, minimum wages and unemployment benefits in the determination of the NAIRU. Now it can be observed that these are typically characteristics, which apply across the whole of the economy. Laws on trade unions, regulation of labor markets, unemployment benefits and minimum wages are characteristics, which apply to the whole economy and do not (in general) vary from area to area. ${ }^{7}$ It is, we suggest, implausible to think that the variations in unemployment, which are observed between the different regions of a country (or indeed between say urban and rural areas, or between ethnic groups) can be explained by variations in the labor market characteristics of the regions involved. It is much more plausible to view the variations in unemployment as arising from the industrial structure of a region and from variations in productive capacity as well as in aggregate demand of the region.

In contrast, the inflation barrier approach, which we have outlined above readily explains the differences in unemployment across regions in terms of differences in capacity and differences in the demand for the products of a region. Further, if differences in the position of the p-curve across regions (through differences in productive capacity) are substantial, then there would be the observation that across regions there is a positive relationship between real wage and employment as the w-curve is mapped out. This would be consistent with the findings of a wage curve with such a positive relationship (see, for example, Blanchflower and Oswald, 1994).

\subsection{Declining Unemployment and Low Inflation in the 1990s}

After 1992, Canada, U.S. and UK experienced declining unemployment and generally declining inflation. France and Germany also experienced generally declining inflation but alongside rising unemployment in the case of Germany, and rising then falling around a high level in France. These experiences during the 1990s are well illustrated in Charts 1 and 2. The combination of falling unemployment and declining inflation in Canada, UK and U.S. is notable. At the beginning of the 1990s, most estimates of the NAIRU for the U.S. were in the range of 5.5 to 6.5 percent, $^{8}$ while for the U.K. NAIRU estimates ranged from 6 to 8

\footnotetext{
7 There are exceptions to this: for example, the minimum wage may differ across regions reflecting perceived differences in the cost of living. In a Federal system, such as the U.S., there can be variations in the employment laws.

8 "Tightness in the labor market is measured by the excess of CBO's estimate of the nonaccelerating inflation rate of unemployment (NAIRU) over the actual unemployment rate. It is an indicator of future wage inflation" (Congressional Budget Office, 1994, p. 4), and that Office uses an estimate of 6 percent for the NAIRU.
} 
percent. ${ }^{9}$ The estimates of OECD (2000) for the five countries considered here are given in Table 2. As is generally the case, estimates of the NAIRU tend to track the path of observed unemployment.

We suggest here that the relative experience of these five countries is consistent with the arguments advanced above. From 1992 onwards, Canada, UK and U.S. experienced high rates of growth of investment, whereas France and Germany did not. This is illustrated in Chart 3. Between 1992 and 1999, private sector non-residential investment grew by 95 percent in U.S., 64 percent in Canada and 58 percent in the UK, whereas it grew by 3.5 percent in Germany and 16 percent in France. On OECD estimates, all five countries had a substantial negative output gap in 1993. However, the growth of investment and of the capital stock meant that the decline in unemployment in Canada, UK and U.S. went alongside only modest rises in the gap between actual output and capacity output.

\section{SUMMARY AND CONCLUSIONS}

A formal model of the inflationary process has been put forward, which may be characterized as the structuralist view of inflation. The key elements of this view have been put together in a formal model. We have argued that the essentials of this model are validated by existing empirical evidence. We have also used the 1990s experience in relation to unemployment and inflation. The conclusions reached in this part of the paper provide additional support to the structuralist model proposed in this study.

\footnotetext{
9 "The sustainable rate of unemployment, or NAIRU, is believed to have risen in the UK during the 1970s and $1980 \mathrm{~s}$, but there is broad agreement that this increase has been partly reversed since the late 1980s. Although the magnitude of any fall is very difficult to estimate, most estimates of the current level of the NAIRU lie in the range of 6 to 8 percent on the LFS measure of unemployment. However, considerably lower levels should be achievable in the long run through re-integrating the long-term unemployed back into the labor market, upgrading skills, and reforming the tax and benefit systems to promote work incentives" (Treasury, 1997, p.82).
} 
TABLE 1: Estimates of Depth of Recession or Scale of Fast Growth as Compared with Trend in the UK* in Terms of GDP Growth

\begin{tabular}{|l|l|l|l|l|}
\hline & & & Estimate & \\
\hline Recession & Start & End & Method A & Method B \\
\hline 1 & 1920 & 1921 & -10.3 & -10.3 \\
\hline 2 & 1929 & 1932 & -11.9 & -11.9 \\
\hline 3 & 1973 & 1975 & -7.8 & -8.3 \\
\hline 4 & 1979 & 1982 & -10. & -10.0 \\
\hline 5 & 1989 & 1993 & -11.6 & -10.4 \\
\hline $\begin{array}{l}\text { Fast growth } \\
\text { phases }\end{array}$ & & & & \\
\hline 1 & 1922 & 1925 & 4.7 & 4.7 \\
\hline 2 & 1933 & 1937 & 9.5 & 8.5 \\
\hline 3 & 1972 & 1973 & 4.1 & 4.3 \\
\hline 4 & 1985 & 1988 & 7.4 & 6.4 \\
\hline
\end{tabular}

Notes:

* Percentage change in output from start to end of recession or fast-growth phase less (years $\mathrm{x}$ annual trend percentage growth rate)

Method A "assumes changes in percentage of labor unemployment during a major recession measure the degree to which overall economic capacity is unemployed."

Method B "makes use of the short-term relationship between output and employment."

Source and Quotes: Dow (1998). 
TABLE 2: Estimates of NAIRU and Actual Unemployment (percent of labor force)

\begin{tabular}{lcccccc} 
& Estimates of & NAIRU & \multicolumn{2}{c}{ Actual Unemployment } & \multicolumn{2}{c}{ Change, 1990-1999 } \\
& 1990 & 1999 & 1990 & 1999 & NAIRU & Actual \\
France & 9.3 & 9.5 & 8.6 & 11.1 & 0.2 & 2.5 \\
Germany & 5.3 & 6.9 & 4.8 & 8.3 & 1.6 & 3.5 \\
Canada & 9.0 & 7.7 & 8.1 & 7.6 & -1.3 & -0.5 \\
UK & 8.6 & 7.0 & 6.9 & 6.0 & -1.6 & -0.9 \\
U.S. & 5.4 & 5.2 & 5.6 & 4.2 & -0.2 & 1.4
\end{tabular}

Source: OECD (2000), Table V.1, Annex Table 21

Note: Unemployment rates (actual and NAIRU) are measured on commonly used national definitions. 


\section{REFERENCES}

Alexiou, C. and Pitelis, C. 2003. "On Capital Shortages and European Unemployment: A Panel Data Investigation.” Journal of Post Keynesian Economics 25(4): 613-631.

Arestis, P. and Mariscal, I. 1997. "Conflict, Effort and Capital Stock in UK Wage Determination." Empirica 24(3): 179-193.

Arestis, P. and Mariscal, I. 1998. "Capital Shortages and Asymmetries in UK Unemployment.” Structural Change and Economic Dynamics 9(2): 189-204.

Arestis, P. and Biefang-Frisancho Mariscal, I. 2000. "Capital Stock, Unemployment and Wages in the UK and Germany." Scottish Journal of Political Economy 47(5): 487-503.

Baddeley, M. C. 2003. Investment: Theories and Analysis. Basingstoke, UK: Palgrave Macmillan.

Baker, D., Glyn, A. Howell, D. and Schmitt, D. 2002. "Labor Market Institutions and Unemployment: A Critical Assessment of the Cross-Country Evidence." CEPA Working Paper 2002-17, 8 November. New York: New School University.

Bernanke, B. S. and A. S. Blinder. 1988. "Credit, Money and Aggregate Demand." American Economic Review 78(2): 435-439.

Bernanke, B. S. and M. Gertler. 1989. "Agency Costs, Net Worth, and Business Fluctuations." American Economic Review 79(1): 14-31.

Bernanke, B. S. and M. Gertler. 1999. "Monetary Policy and Asset Price Volatility." In New Challenges for Monetary Policy. Proceedings of the Symposium Sponsored by the Federal Reserve Bank of Kansas City, Jackson Hole, Wyoming, 77-128.

Bhadhuri, A. and Marglin, S. 1990. "Unemployment and the Real Wage: The Economic Basis for Contesting Political Ideologies." Cambridge Journal of Economics 14(4): 375393.

Blanchflower, D. G. and Oswald, A. J. 1994. The Wage Curve. Cambridge, Mass.: M.I.T. Press.

Chirinko, R. S. 1993. "Business Fixed Investment Spending: Modeling Strategies, Empirical Results, and Policy Implications." Journal of Economic Literature 31(4): 1875-1911.

Congressional Budget Office. 1994. The Economic and Budget Outlook: Fiscal Years 19962000. Washington, D.C.: Congressional Budget Office.

Dow, J C R. 1998. Major Recessions: Britain and the World, 1920-1995. London and New York: Oxford University Press.

Elsmeskov, J., Martin, J. and Scarpetta, S. 1998. "Key Lessons for Labor Market Reforms: Evidence from OECD Countries Experience.” Swedish Economic Policy 5(2): 205-252. 
Fazzari, S. 1993. "Monetary Policy, Financial Structure, and Investment." Chapter 3 in Transforming the U.S. Financial System: Equity and Efficiency for the $21^{\text {st }}$ Century, Armonk, New York: M. E. Sharpe.

Fazzari, S. and Peterson, B. 1993. "Working Capital and Fixed Investment: New Evidence on Financing Constraints." Rand Economic Journal 24: 328-342.

Friedman, M. 1968. "The Role of Monetary Policy.” American Economic Review 58(1): 117.

Gordon, R. J. 1997. "The Time-Varying NAIRU and its Implications for Economic Policy." Journal of Economic Perspectives. 11(1): 11-32.

Greenspan, A. 2002. "Issues for Monetary Policy." Remarks Before the Economic Club of New York, New York City, December 19. Paper available online at: http://www.federalreserve.gov/boarddocs/speeches/2002/20021219/ (pages in the text refer to the website document).

Hubbard, R. G. 1998. "Capital-Market Imperfections and Investment.” Journal of Economic Literature, XXXVI(1): 193-225.

Issing, O. 2003. Testimony before the Committee on Economic and Monetary Affairs of the European Parliament, Brussels, 24 March. Paper available online at: http://www.ecb.int.

Kalecki, M. 1943. "The Determinants of Investment." In Studies in Economic Dynamics. London: Allen and Unwin.

Layard, R., Nickell, S. and Jackman, R. 1991. Unemployment: Macroeconomic Performance and the Labor Market. Oxford: Oxford University Press.

Layard, R., Nickell, S. and Jackman, R. 1994. The Unemployment Crisis, Oxford: Oxford University Press.

Miaouli, N. 2001. "Employment and Capital Accumulation in Unionized Labor Markets." International Review of Applied Economics. 15(1): 5-30.

Minsky, H. P. 1975. John Maynard Keynes. New York: Columbia University Press.

Nickell, S. 1997."Unemployment and Labor Market Rigidities: Europe versus North America." Journal of Economic Perspectives. 11(3): 55-74.

Nickell, S. J. and Layard, R. 1999. "Labor Market Institutions and Economic Performance." In O. Ashenfelter and D. Card, eds. Handbook of Labor Economics Vol. 3. Amsterdam: North Holland.

OECD. 1994a. OECD Jobs Study, Evidence and Explanations, Part I: Labor Market Trends and Underlying Forces of Change. Paris, France: OECD.

OECD. 1994b. OECD Jobs Study, Evidence and Explanations, Part II: The Adjustment Potential of the Labor Market. Paris, France: OECD. 
OECD. 1994c. OECD Jobs Study, Taxation Employment and Unemployment. Paris, France: OECD.

OECD. 1999. OECD Employment Outlook, June. Paris, France: OECD.

OECD. 2000. OECD Economic Outlook, December. Paris, France: OECD.

Palley, T. 2000. "Evaluating the OECD's Job Strategy: Has it Helped Lower Unemployment?," AFL-CIO Technical Working Paper, T024.

Palley, T. 2001. "The Role of Institutions and Policies in Creating High European Unemployment: The Evidence.” Working Paper No. 336. Annandale-on-Hudson, N.Y.: The Levy Economics Institute.

Rowthorn, R. 1995. "Capital Formation and Unemployment." Oxford Review of Economic Policy 11(1): 26-39.

Sargan, J. D. 1964. "Wages and Prices in the United Kingdom: A Study in Econometric Methodology." In P. E. Hart, G. Mills and J. K. Whitaker, eds. Econometric Analysis for National Economic Planning. London: Butterworths, 25-63.

Sawyer, M. 1982a. Macro-Economics in Question. Brighton: Wheatsheaf Books, and New York: M.E. Sharpe.

Sawyer, M. 1982b. "Collective Bargaining, Oligopoly and Macro-Economics." Oxford Economic Papers 34(4): 428-448.

Sawyer, M. 1983. Business Pricing and Inflation, London: Macmillan and New York: St. Martin's Press.

Sawyer, M. 2002. "The NAIRU, Aggregate Demand and Investment." Metroeconomica 53(1): 66-94.

Siebert, H. 1997. "Labor Market Rigidities: At the Root of Unemployment Problem." Journal of Economic Perspectives 11(3): 37-54.

Stiglitz, J. and Weiss, A. 1981. "Credit Rationing in Markets with Imperfect Information," American Economic Review 71(3): 393-410.

Stockhammer, E. 2004. "Explaining European Unemployment: Testing the NAIRU Hypothesis and a Keynesian Approach." International Review of Applied Economics, vol. 18 forthcoming (pages in the text refer to the mimeo version).

Treasury. 1997. Pre Budget Report. Cmnd. 3804. London: HMSO. 


\section{FIGURE 1}

Real wage

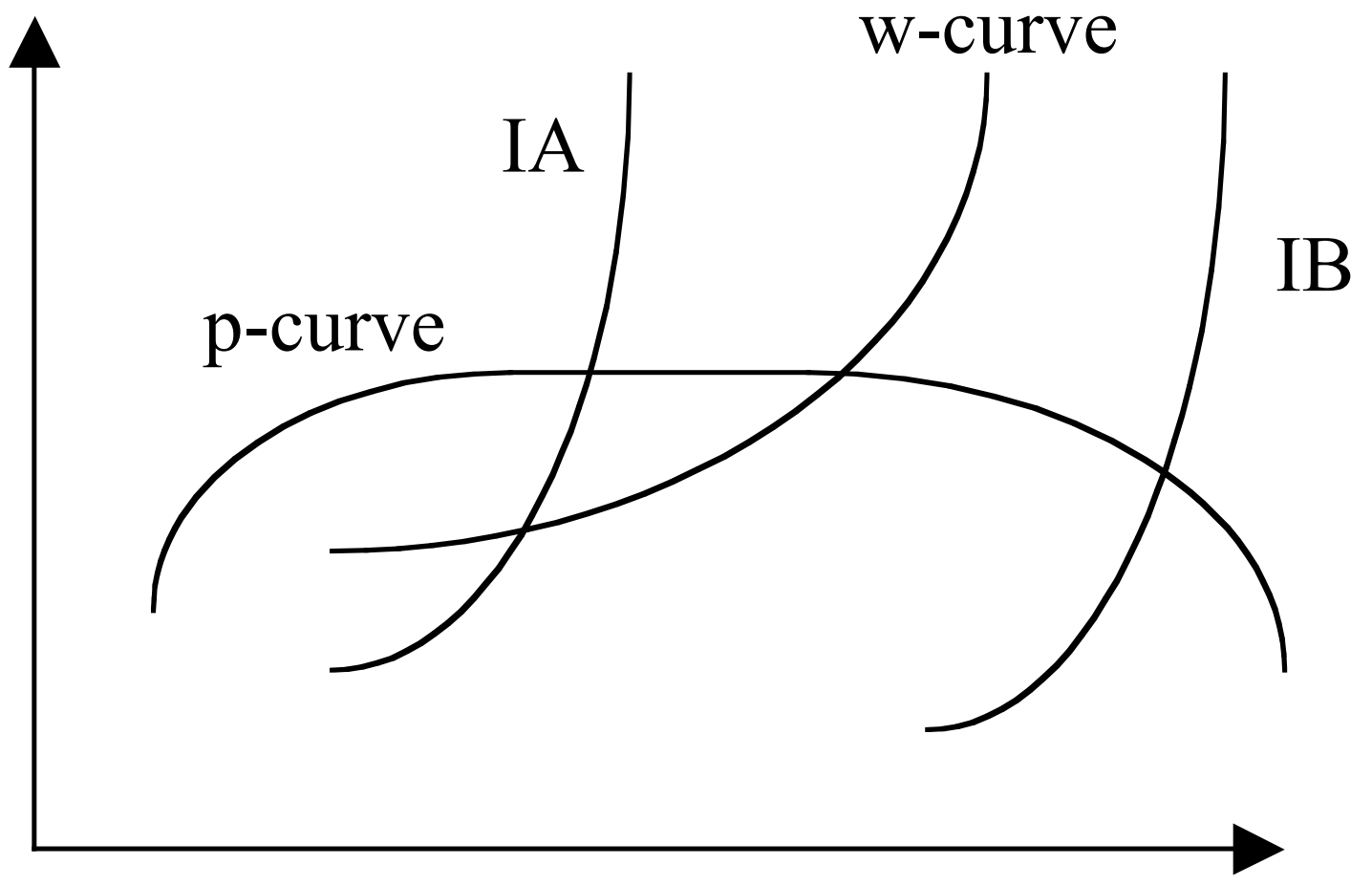

Employment 


\section{FIGURE 2}

Real Wage

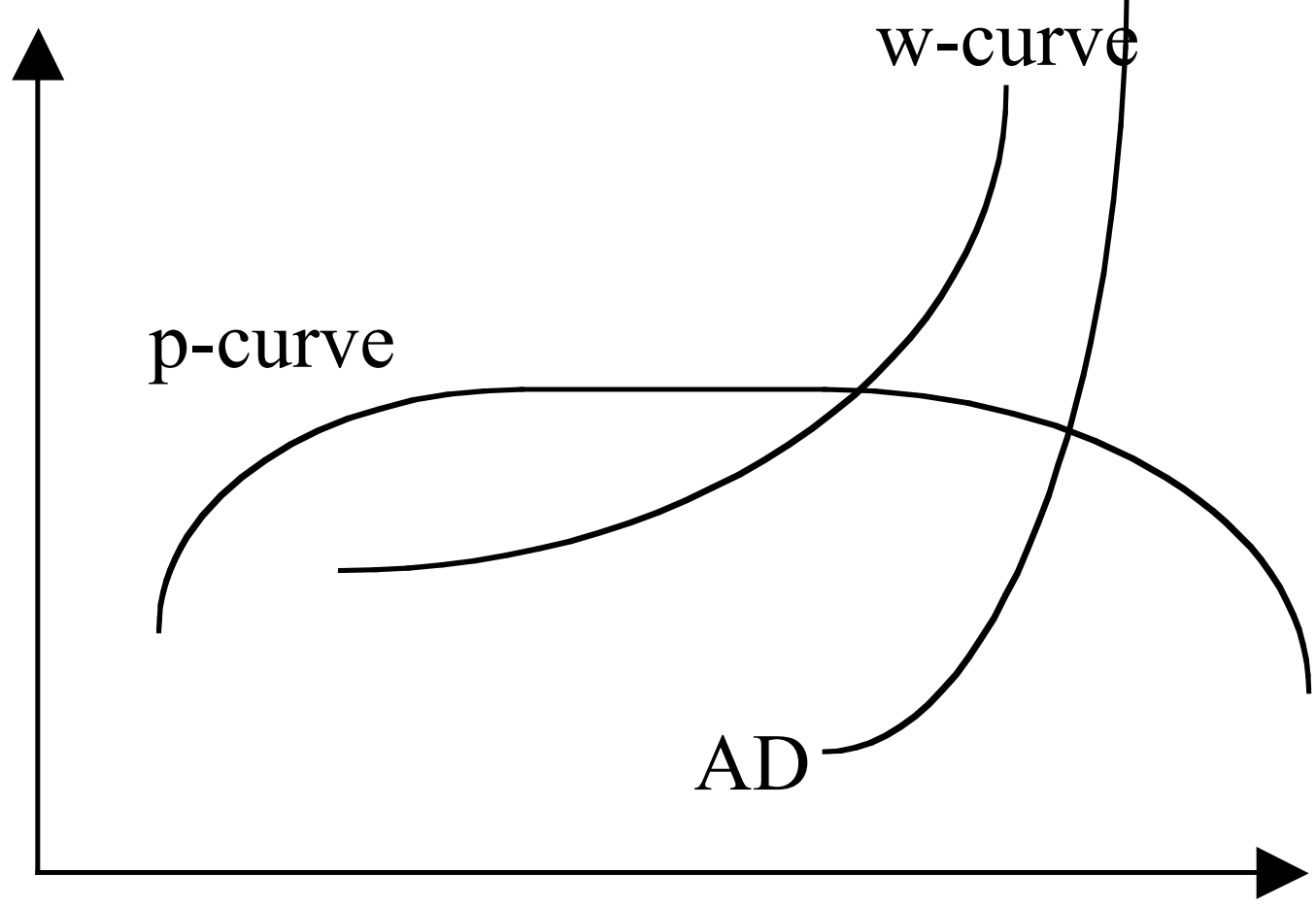

Employment 


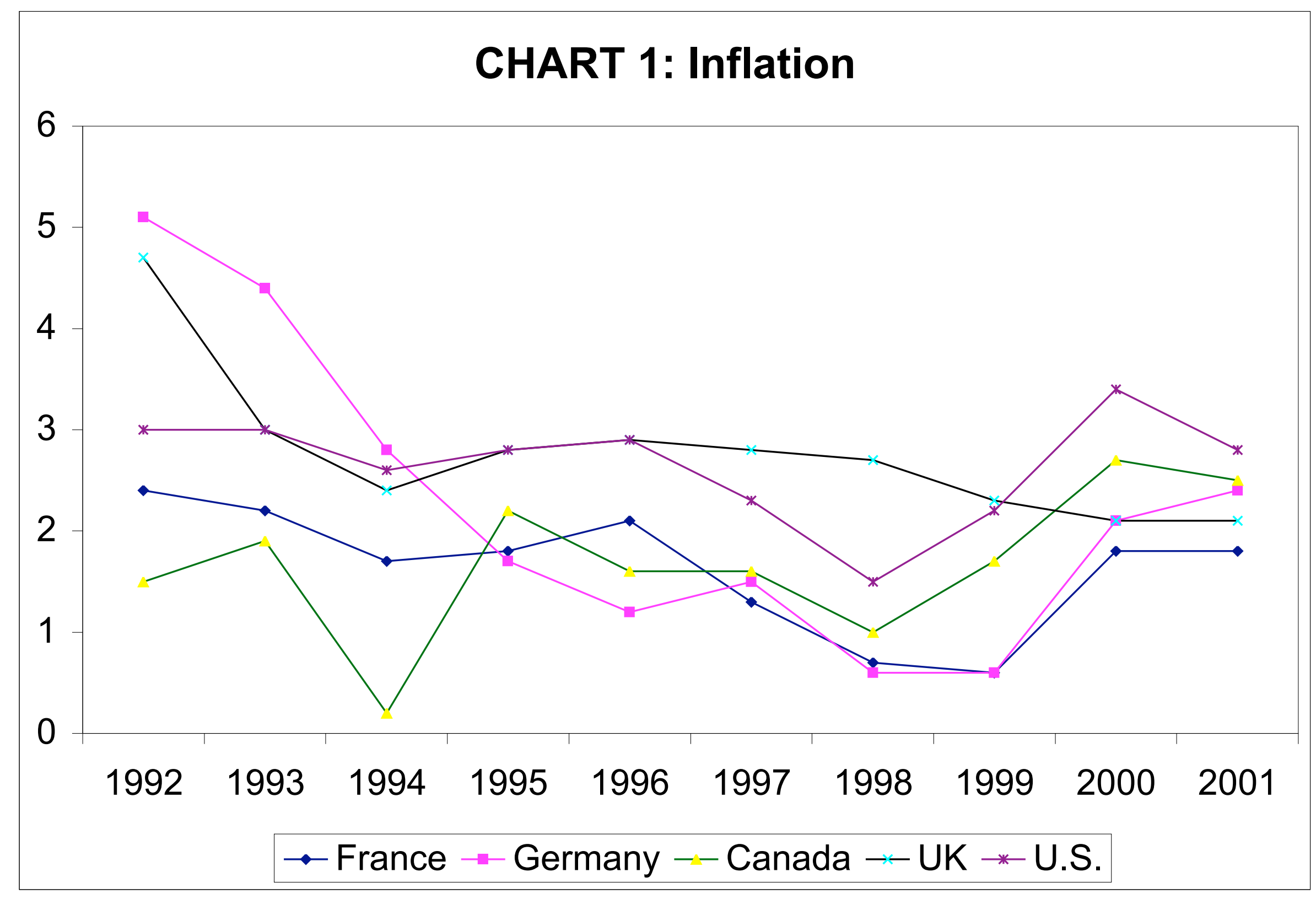




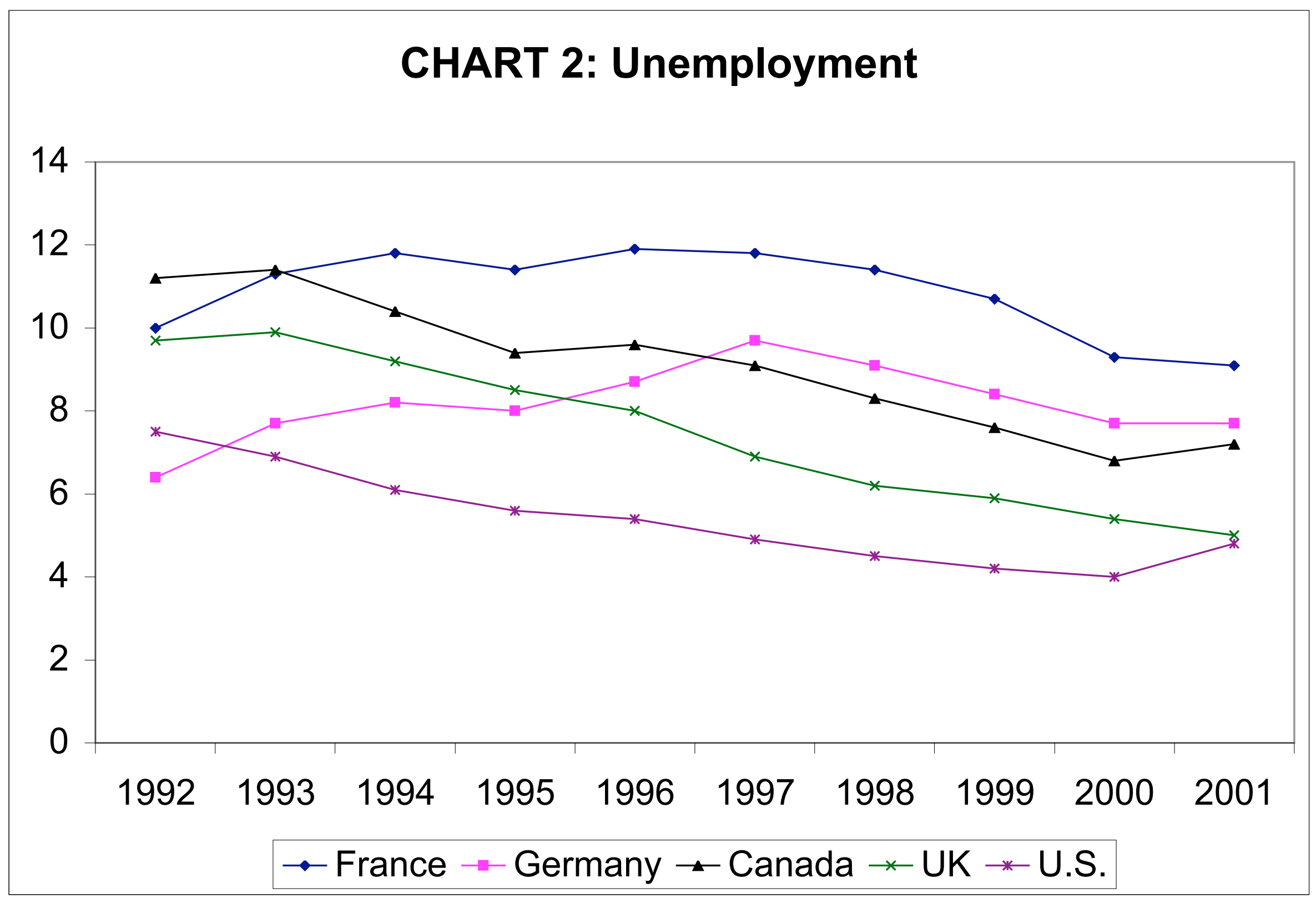




\section{CHART 3: Growth of investment}

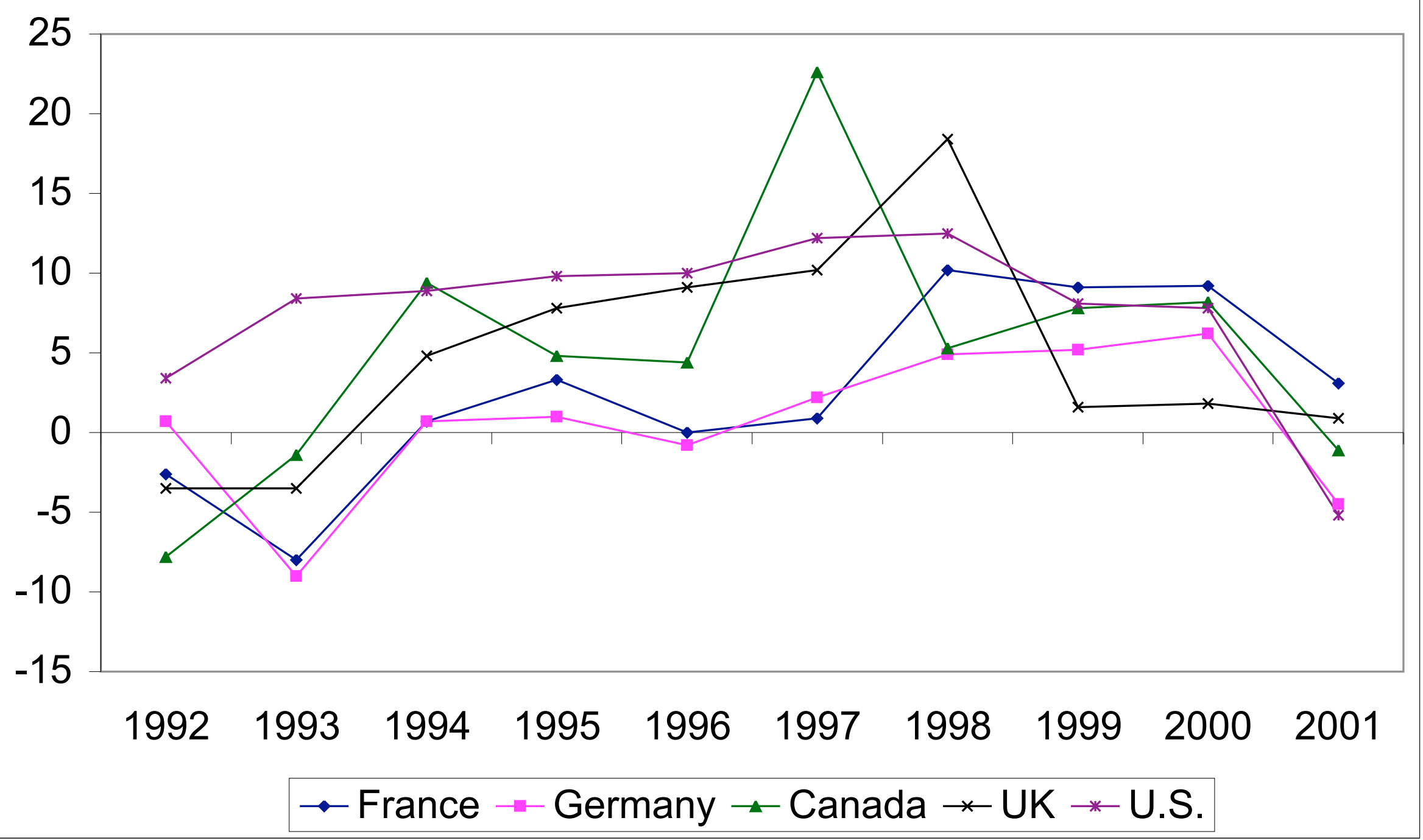

